\title{
Comparison of Certain Physical Fitness Parameters in Young Football and Basketball Players
}

\author{
Murat Akyüz \\ Correspondence: Murat Akyüz, Faculty of Sport Sciences, Manisa Celal Bayar University, Manisa, 45040, Turkey.
}

Received: April 9, 2018

doi:10.11114/jets.v6i5.3189
Online Published: April 27, 2018

URL: https://doi.org/10.11114/jets.v6i5.3189

\begin{abstract}
This study was carried out in order to compare certain physical fitness parameters of young basketball and football players. Basketball players, who are playing in U16 league $(n=12)$, and football players playing in U17 league $(n=10)$ participated in the study voluntarily. Groups were separated into two as the basketball group (BG) and the football group (FG). BG has a body weight mean of $74.13 \pm 7.26 \mathrm{~kg}$, a height mean of $187.50 \pm 7.03 \mathrm{~cm}$, and an age mean of 16 . FG has a body weight mean of $68.0 \pm 7.95 \mathrm{~kg}$, a height mean of $178.4 \pm 5.31 \mathrm{~cm}$, and an age mean of 17. Participants were applied performance tests, which are composed of sit and reach test, leg strength, hand grip strength, flexibility, 20 $\mathrm{m}$ sprint, and flamingo balance test among physical fitness parameters. Data obtained were analysed using SPSS 19.0 package program, and Mann Whitney $U$ test was used to compare two groups. While there was no meaningful difference between strength and flexibility values ( $>0.05$ ), a meaningful difference occurred in favour of FG in $20 \mathrm{~m}$ speed test $(\mathrm{p}<0.05)$. As a result, the difference that occurred in speed only makes us think that height and body weight in basketball players can impact speed and agility negatively compared to football players.
\end{abstract}

Keywords: flexibility, balance, leg strength, hand grip strength, football, basketball

\section{Introduction}

Physical fitness is the work capacity of a person and his ability to perform actions in a correct and successful way (Zorba \& Saygin, 2009). Physical fitness can be segmented into its components as health-related and skill-related, which can be measured in two groups. Skill-related physical fitness can be listed as agility, balance, speed, coordination, power and attention. Agility is the ability of the body to perform in a fast, proper and controlled way the actions that are demanded from it. Coordination is the ability of the body to carry out senses such as visual or audio together with motoric movements, which are performed by one or more organs, in a harmonic and proper manner simultaneously. Reaction time is the duration between determination of the movement to be performed and the moment of acting. Speed is the ability to perform the desired movement in a short time interval (Akyüz et al., 2017). Balance is the ability to keep proper stance while standing firm or moving (Karagül et al, 2017; Akyüz, 2017).

Sport has become an indispensable elements of the modern world, and movement is an essential need for individuals (Akyüz et al., 2016; Çay et al., 2018). Importance placed by developed countries on sport as well as their achievements in sport are the most significant indicator of this. Today, it is known that there are numerous physical and psychological determinant factors on the ability of success-oriented athletes' ability to produce work output. Thus, it would be suitable to accept the work ability of the athlete, which takes place despite all negative factors along with all positive factors, as the resultant of the output quality and capacity. In this regard, all factors affecting performance components must be taken into consideration (Bayraktar \& Kurtoğlu, 2009). Although sport performance essentially seems to be related to the body structure, gender and age of the athlete, it is also dependant on some other measurable and improvable properties. Expedient properties must be developed in order to succeed in a sports branch. For instance, one cannot expect a long-distance runner, paddler or archer to have the same body properties. Nevertheless, performance has measurable elements that are common for all sports branches (Akgün, 1996). Today, the popularity of football being at the peak compared to other sports branches leads the majority of parents to direct their children to football, and the children taking place in football easier in future depends largely on their physical and motoric developments (Taşkın et al., 2015; Akyüz, 2017b). Like football, basketball is also a sport that has a lot of participants and audiences. As in all team sports, when game duration as well as the requirement to play quickly and correctly are taken into consideration in addition to physical properties; biomotor properties such as power, speed, endurance, mobility and coordination, and parameters such as technique and tactics and experience have importance in achieving success (Bakırcı \& Kılınç, 2014). 
Starting from childhood and adolescent periods, moves that are specific to basketball are taken to a superior level by improving them through technical works and trainings in adulthood period. In professional sports, training techniques are based on increasing and improving performance of athletes, and detecting and eliminating the deficiencies in significant physical fitness parameters. Implementation of technical and tactical trainings within the game and in positions, that change instantly, is a major factor in improvement of properties such as coordination and reaction. The fact that athletes reflect the physical, psychological and other impacts of trainings on their skills is essential for their optimal functions, success, and prevention of injuries (Rhea et al., 2008). Today, there are many studies performed by experts that can develop and improve the physical fitness parameters of athletes in order to increase their success (Harris et al., 2000).

Numerous physical and physiological specific to many sports exist. Studies, which have been carried out on determination of sportive capacities, have shown that sportive skill is a whole (Akyüz et al., 2016b). Hence, having knowledge on physical and physiological needs of athletes during contests as well as reviewing the fundamentals of the game is inevitable (Ocak et al., 2014). In this context, the aim of the study is to compare power, flexibility, speed and balance from physical fitness parameters in young football and basketball players.

\section{Method}

\subsection{Participants}

Basketball players, who are playing in U16 league $(n=12)$, and football players playing in U17 league $(n=10)$ participated in the study voluntarily. Groups were divided into two as basketball group (BG) and football group (FB). Participants were applied performance tests, which are composed of sit and reach test, leg strength, hand grip strength, flexibility, $20 \mathrm{~m}$ sprint, and flamingo balance test among physical fitness parameters.

\subsection{Test Protocols}

Body weight was measured with Tanita body composition analyser (Tanita TBF 300 M, Tokyo-Japan). Measurements were performed by removing metal accessories on the participants, with body straight and face looking fully across, and by stepping barefoot on places specified in the device and with minimum amount of clothes. Height was measured with Seca 769 (Hamburg, Germany) having a sensitivity degree of $0.01 \mathrm{~cm}$. Volunteers had no clothes on their feet and head sections that could change the measurement (Akyüz, 2017b).

Vertical Jump Test: Athlete stands on two feet near a wall. With his fingers pressed on chalk powder, he extends his arm and marks the wall. At this point, care must be given to the fact that the athlete does not raise his feet off the ground, and his arm length is complete. Standing in the same position, he jumps with his full strength and leaves mark on the highest point he can touch. The distance between these 2 points gives the athlete's vertical jump height. This is repeated for 3 times and the best rating is selected. A rest time of 30 to 60 seconds is given for recovery between each jump (Akyüz, 2017b).

Sit and Reach Flexibility Test: Test stand is $35 \mathrm{~cm}$ long, $45 \mathrm{~cm}$ wide and $32 \mathrm{~cm}$ high. Sit and reach test was used to measure the flexibility of hamstring and back muscles. Subjects placed their soles on the sit and reach stand and waited firm by reaching forward as much as they could, and the distance that could be reached was recorded in centimetres. Test was repeated for two times and the best result was accepted as the flexibility value (Tamer, 2000; Zorba, 1999).

Hand Grip Strength Test: Measurements were performed with Takei brand hand dynamometer (hand grip). Following 5 minutes of warm-up, measurement was taken while the subject was standing still without bending the arm or contacting it with the body, and while the arm had an angle of 45 degrees to the body. This test was repeated for 3 times and the highest value was recorded (Özer, 2006).

Back Strength Test: Measurement was performed using Takei brand dynamometer (T.K.K. 5102 Back- D, Takei Scientific Inst.Co., Imt.). After placing their feet on the dynamometer stand with the knees stretched; athletes were asked to pull up at the maximum rate the dynamometer bar they gripped with their hands with the arms stretched, back straight, and the body bent slightly forward, and the highest value was recorded after 3 trials (Zorba, 1999).

Leg Strength Test: Measurements were performed using Takei brand back and leg dynamometer. Following 5 minutes of warm-up, after placing their feet on the dynamometer stand with their knees bent; subjects pulled up vertically using their legs at the maximum rate the dynamometer bar which they gripped with their hands with the arms stretched, back straight, and the body bent slightly forward. This measurement was repeated for 3 times and the highest value was recorded (Tamer, 2000).

Speed Performance Test: Athletes ran with their maximum power the distance in the gym, which was determined as 20 $\mathrm{m}$, by starting on their own. The test was applied on the athletes twice with 2 minutes of rest time. Their ratings were recorded with chronometer in seconds and the best rating was taken into consideration (Akyüz, 2017b). 
Flamingo Balance Test: Its aim is to detect how many seconds within a minute the subject's static balance lasts. Balancing equipment was positioned and the researcher sat in stool before it with chronometer in his hand. One more person stood near the balancing equipment to ensure the balance of the subject and count the number of mistakes. Chronometer was started after the subject ensured his balance. It was measured how many seconds he maintained his balance within a minute. Chronometer was stopped when his foot in the air touched the ground or he fell off, losing his balance, and was restarted after he ensured his balance. The shortest of the two practises was extracted, the best practise was taken and recorded as test point (Altınkök \& Ölçücü, 2012).

\subsection{Statistical Analysis}

Data were analysed with SPSS 19.0 package program and Mann Whitney U test was used to compare two groups. In addition, descriptive statistics for the heights, weights, ages and sport ages of the participants were displayed as minimum, maximum, mean and standard deviations. Meaningfulness was taken as $\mathrm{p}<0.05$.

\section{Results}

Basketball group had body weight of $74.13 \pm 7.26 \mathrm{~kg}$, height of $187.50 \pm 7.03$ and age of $16.0 \pm 0.0$. Football group had body weight of $68.0 \pm 7.95$, height of $178.4 \pm 5.31$ and age 17.0 \pm 0.0 (Table 1).

Table 1. Descriptive parameters of BG and FG

\begin{tabular}{lcccccc}
\hline \multirow{2}{*}{ Parameters } & \multicolumn{3}{c}{ BG $(\mathrm{n}=12)$} & \multicolumn{3}{c}{ FG $(\mathrm{n}=10)$} \\
\cline { 2 - 7 } & Minimum & Maximum & Mean \pm SD & Minimum & Maximum & Mean \pm SD \\
\hline Height $(\mathrm{cm})$ & 173 & 197 & $187.50 \pm 7.03$ & 170 & 187 & $178.4 \pm 5.31$ \\
Body Weight $(\mathrm{kg})$ & 66.4 & 87 & $74.13 \pm 7.26$ & 57 & 82 & $68.0 \pm 7.95$ \\
Age (years) & 16.00 & 16.00 & $16.0 \pm 0.0$ & 17 & 17 & $17.0 \pm 0.0$ \\
Athlete Age (year) & 5 & 10 & $7.58 \pm .1 .31$ & 4 & 4 & $4.0 \pm 0.0$ \\
\hline
\end{tabular}

While no meaningfulness was found in power and flexibility values of the participants in statistical terms ( $>0.05)$, a meaningful difference occurred in $20 \mathrm{~m}$ sprint values between two groups $(\mathrm{p}<0.05)$, and this difference is in favour of FG. (Table 2).

Table 2. Comparison of the physical fitness parameters of BG and FG

\begin{tabular}{|c|c|c|c|c|c|c|c|}
\hline \multirow{2}{*}{ Parameters } & \multicolumn{3}{|c|}{$\mathrm{BG}(\mathrm{n}=12)$} & \multicolumn{3}{|c|}{$\mathrm{FG}(\mathrm{n}=10)$} & \multirow{2}{*}{$\mathrm{P}$} \\
\hline & Minimum & Maximum & Mean \pm SD & Minimum & Maximum & Mean \pm SD & \\
\hline Sit and Reach $(\mathrm{cm})$ & 5 & 20 & $13.18 \pm 4.7$ & 4.00 & 22.50 & $15.55 \pm 6.10$ & .259 \\
\hline \multicolumn{8}{|l|}{ Right Hand } \\
\hline \multicolumn{8}{|l|}{ Grip (kg) } \\
\hline Left Hand Grip (kg) & 26.1 & 52.2 & $41.40 \pm 7.59$ & 30.10 & 53.60 & $42.10 \pm 7.67$ & .916 \\
\hline Back Strength (kg) & 56.0 & 157.0 & $104.20 \pm 20.9$ & 56.50 & 164.0 & $124.30 \pm 33.28$ & .260 \\
\hline Leg Strength (kg) & 54.5 & 151.5 & $108.40 \pm 30.65$ & 52.50 & 148.0 & $108.0 \pm 32.3$ & 1,000 \\
\hline $20 \mathrm{~m}$ sprint & 3.56 & 4.16 & $3.76 \pm .18$ & 2.9 & 3.8 & $3.47 \pm .3$ & $.028^{*}$ \\
\hline Flamingo Balance Test (seconds) & .00 & 38 & $25.30 \pm 10.1$ & 24 & 43 & $31.50 \pm 6.83$ & .255 \\
\hline
\end{tabular}

$* \mathrm{p}<0.05$

\section{Discussion and Results}

Recently, impact of certain physical fitness variables on performance appears as popular research topics for many researchers working in the area of sports sciences (Güler et al., 2010; Bilgiç et al., 2016).

In another study performed, $30 \mathrm{~m}$ sprint mean of 60 basketball players aged 13-16 was detected as $4.77 \pm 0.24$ seconds (Bayramoğlu, 1998). Ateş et al. reported $30 \mathrm{~m}$ sprint mean of 12 football players aged 14-16 as $4.62 \pm 0.22$ seconds. In the study they performed, Kürkçü et al. (2009) reported $30 \mathrm{~m}$ sprint mean of 18 U18 football players as $4.15 \pm 0.52$. 
When the groups were compared in this study, $20 \mathrm{~m}$ sprint mean was found to be meaningfully low compared to basketball players. Literature findings show parallelism with the values obtained. Good speed property is an important motoric property for performance in football. Speed is also one of the essential motoric properties for good performance in basketball. However, it is considered that height and body weight can impact speed and agility properties negatively, hence speed property was meaningfully low in favour of football players.

In his study, İbiş (2002) reported the flexibility value mean of 18 football players aged $12-14$ as $30.77 \pm 3.17 \mathrm{~cm}$, while Erol (1995) reported the flexibility values of 24 basketball players aged 13-14 as $22.21 \pm 4.45 \mathrm{~cm}$. In another study performed with 12 football players aged 14-16, flexibility value of the athletes was detected as $24.66 \pm 4.61 \mathrm{~cm}$ (Ateş et al., 2007). While this study contained no meaningful difference as well, flexibility values were found to be lower compared to football players.

In their study, Pamuk et al., (2008) found grip strength mean as $45.56 \pm 10.98 \mathrm{~kg}$ in 2 nd league players, while as $36.82 \pm 7.74 \mathrm{~kg}$ in regional basketball league players. In his study, Özbek (2008) detected pre and final measurement values of right hand grip strength of male basketball players aged $15-17$ as $8.93 \pm 5.91 \mathrm{~kg}-46.20 \pm 7.88 \mathrm{~kg}$ in the $1 \mathrm{st}$ test group, and as $36.27 \pm 4.27 \mathrm{~kg}-40.80 \pm 3.97$ in the $2 \mathrm{nd}$ test group. Pre and final measurement values of left hand grip strength were found as $35.13 \pm 4.70 \mathrm{~kg}-41.13 \pm 5.53 \mathrm{~kg}$ in the $1 \mathrm{st}$ test group, and as $33.73 \pm 3.41 \mathrm{~kg}-36.53 \pm 2.67$ $\mathrm{kg}$ in the 2nd test group. In their study, Savucu et al. (2004) detected right hand grip strength measurement value mean of $36 \mathrm{U} 18$ basketball players aged $15.33 \pm 0.47$ years as $49.011 \pm 4.125 \mathrm{~kg}$, and left hand grip strength measurement value mean as $46.755 \pm 5.430 \mathrm{~kg}$. Ateş \& Ateşoğlu (2017) detected right hand grip strength measurement values of male football players of $16-18$ age group as $36.63 \pm 4.48 \mathrm{~kg}$ in 1 st measurement, and as $39.73 \pm 4.88$ in $2 \mathrm{nd}$ measurement. They detected left hand grip strength measurement values as $33.87 \pm 5.30 \mathrm{~kg}$ in $1 \mathrm{st}$ measurement, and as $35.37 \pm 6.33$ in 2nd measurement. As a result of the 8-week quick strength training they performed on wrestlers of 16-17 age group, Gökdemir et al. (1999) detected right hand grip strength values as $47.80 \mathrm{~kg}$ before the training and as $51.74 \mathrm{~kg}$ after the training, while left hand grip strength values as $46.76 \mathrm{~kg}$ before the training, and $44.79 \mathrm{~kg}$ after the training. In his study which he performed by dividing 14-16 age group medium level wrestlers into two groups, Kılıç (1993) found right hand grip strength as $36.28 \mathrm{~kg}$ in the test group and as $35.64 \mathrm{~kg}$ in the control group, while left hand grip strength as $35.09 \mathrm{~kg}$ in the test group and as $33.29 \mathrm{~kg}$ in the control group. In his study, Kızılakşam (2006) detected the right hand grip strength of male students aged 12-14, who are not actively involved in sports, as $23.03 \pm 6.52 \mathrm{~kg}$, and left hand grip strength as $22.63 \pm 5.87 \mathrm{~kg}$. In his study, Özbek (2008) detected the arithmetic mean and standard deviation of back strength and final measurement values of $15-17$ age group male basketball players as $108.93 \pm 21.98 \mathrm{~kg}-123.87 \pm 22.60$ $\mathrm{kg}$ in the 1st test group, and as $101.33 \pm 16.26 \mathrm{~kg}-110.87 \pm 18.09 \mathrm{~kg}$ in the 2nd test group. Kalkavan et al. (1996) found back strength values of $12-15$ age group football players as $79.52 \pm 17.21 \mathrm{~kg}$, and of the sedentary group as $64.5 \pm 14.5 \mathrm{~kg}$. In our study, no meaningful difference could be detected between the groups when evaluation was made in terms of right hand, left hand, and back and leg strength. As a result, branches may have effect for not observing meaningful difference in power, flexibility and balance parameters. The difference, which occurs only in speed, makes one think that height and body weight in basketball players can impact speed and agility properties negatively compared to football players.

\section{References}

Akgün, N. (1996). Egzersiz ve Spor Fizyolojisi. 6. Edition, İzmir: Ege Üniversitesi Printery.

Akyüz, M., Ağar, M., Akyüz, Ö., \& Doğru, Y. (2016). Motivational Factors Affecting Athletes in Selecting the Sport Branches of Athletics, Ski and Tennis. Journal of Education and Training Studies, 4(12), 160-165. https://doi.org/10.11114/jets.v4i12.1961

Akyüz, M., Özmaden, M., Doğru, Y., Karademir, E., Aydın, Y., \& Hayta, Ü. (2017). Effect of static and dynamic stretching exercises on some physical parameters in young basketball players. Journal of Human Sciences, 14(2), 1492-1500. https://doi.org/10.14687/jhs.v14i2.4560

Akyüz, M., Uzaldi, B. B., Akyüz, Ö., \& Doğru, Y. (2016b). Comparison of Sprint Reaction and Visual Reaction Times of Athletes in Different Branches. Journal of Education and Training Studies, 5(1), 94-100. https://doi.org/10.11114/jets.v5i1.1987

Akyüz, Ö. (2017). Effect of Aerobic Loading on Static Balance in Young Athletes. Journal of Education and Training Studies, 5(3), 154-159. https://doi.org/10.11114/jets.v5i3.2177

Akyüz, Ö. (2017b). Examination of basic motoric characteristics with different stretching exercises in football players. Journal of Human Sciences, 14(2), 1255-1262. https://doi.org/10.14687/jhs.v14i2.4547

Altınkök, M., \& Ölçücü, B. (2012). The Examination on Postural Control and Agility Performance of 10 Year Old Tennis Players before the Competition. Selçuk University Journal of Physical Education and Sport Science, 14(2), 
273-276.

Ateş, M., \& Ateşoğlu, U. (2007). The Effect Of Plyometric Training On The Strength Parameters Of Upper And Lower Extremities Of 16-18 Years Old Male Soccer Players. Spormetre Beden Eğitimi ve Spor Bilimleri Dergisi, 5(1), 21-28. https://doi.org/10.1501/Sporm_0000000123

Ateş, M., Demir, M., \& Ateşoğlu, U. (2007). The Effect Of Plyometric Training On Some Physical and Physiological Parameters of 16-18 Years Old Male Soccer Players. Niğde Üniversitesi Beden Ĕ̈itimi ve Spor Bilimleri Dergisi, $1(1), 1-12$.

Bakırc1, A.. \& Kılınç, F. (2014). The Effect Of Applied Combined Training In The Preparatory Periods On The Performance Level Of The University Basketball Team. Inonu University, Journal of Physical Education and Sport Sciences. 1(2). 48-67.

Bayraktar, B., \& Kurtoğlu, M. (2009). Sporda Performans, Etkili Faktörler, Değerlendirilmesi ve Artırılması. Klinik Gelişim Dergisi, 22(1), 16-24.

Bayramoğlu, E. O. (1998). Yıldız ve Genç Erkek Basketbolcularda Morfolojik Yapı ve Performans İlişkileri (Yüksek Lisans Tezi). Akdeniz Üniversitesi, Antalya.

Bilgiç, M., Biçer, M., \& Özdal, M. (2016). Investigation Of Relation 2D:4D Finger Ratio And Sportive Performance Of 11-13 Aged Children Participated In Different Sports. Gaziantep Üniversitesi Spor Bilimleri Dergisi, 1(1), $48-56$.

Çay, V., Buyukyazi, G., Ulman, C., Taneli, F., Doğru, Y., Tıkız, H., ... \& Keskinoğlu, P. (2018). Effects of aerobic plus explosive power exercises on bone remodeling and bone mineral density in young men. Turkish Journal of Biochemistry. https://doi.org/10.1515/tjb-2016-0130

Erol, E. (1995). Yaygın İnterval Metod ile Uygulanan Dayanıklılık Çalışmalarının 13-14 Yaş Grubu Erkek Basketbolcuların Aerobik-Anaerobik Güç, Vücut Kompozisyonu ve Bazı Fizyolojik Parametreler Üzerine Etkilerinin İncelenmesi (Doktora Tezi). Gazi Üniversitesi, Ankara.

Gökdemir, K., Çeker, B., \& Cicioğlu, İ. (1999). Çabuk Kuvvet Antrenmanlarının 16-17 Yaş Grubu Güreşçilerin Bazı Fiziksel ve Fizyolojik Parametreleri Üzerine Etkisi. Selçuk Üniversitesi Beden Eğitimi Ve Spor Bilimleri Dergisi, $1(1), 36-43$.

Güler, D., Kayapınar, F., Pepe, K., \& Yalçıner, M. (2010). The physical, physiological, technical characteristics of the children who took place in the football championship and the factors affecting their performance . Genel Tip Derg, 20(2), 43-49.

Harris, G. R., Stone, M. H., O'bryant, H. S., Proulx, C. M., \& Johnson, R. L. (2000). Short-term performance effects of high power, high force, or combined weight-training methods. The Journal of Strength \& Conditioning Research, 14(1), 14-20.

İbiş, S. (2002). Yaz Spor Okuluna Katılan 12-14 Yaş Grubu Erkek Futbolcuların Bazı Fiziksel ve Fizyolojik Parametrelerinin İncelenmesi (Yüksek Lisans Tezi). Niğde Üniversitesi, Niğde.

Kalkavan, A., Zorba, E., Ağaoğlu, S.A., Karakuş, S., \& Çolak, H. (1996). A Comparison Of Different Sports Branches' Players And Sedentary Group's Physical Fitness Parameters. Gazi Beden Ĕ̈itimi ve Spor Bilimleri Dergisi, 1(3), 25-35.

Karagul, O., Nalcakan, G. R., Dogru, Y., \& Tas, M. (2017). Effects of Circadian Rhythm on Balance Performance. Polish Journal of Sport and Tourism, 24(3), 155-161. https://doi.org/10.1515/pjst-2017-0016

Kılıç, R. (1993), Dairesel Çabuk Kuvvet Antrenmanını 14-16 Yaş Grubu Erkek Grubu Erkek Güreşçilerin Bazı Özelliklerine Etkisi (Yüksek Lisans Tezi) Gazi Üniversitesi, Ankara.

Kızılaksam, E. (2006), Edirne İl Merkezi İlköğretim Okullarındaki 12-14 Yaş Grubu Aktif Olarak Spor Yapan ve Yapmayan (Beden Eğitimi Dersine Giren) Öğrencilerin Eurofit Test Bataryaları Uygulama Sonuçlarının Karşılaştırılması (Yüksek Lisans Tezi) Trakya Üniversitesi, Edirne.

Kürkçü, R., Afyon, Y. A., Yaman, Ç., \& Özdağ, S. (2009). Comparison of some physical and physiologic properties of soccer players and badminton players of 10-12 years old group. Uluslararast Insan Bilimleri Dergisi, 6(1), 547-556.

Ocak, Y., Savaş, S., Işık, Ö., \& Ersöz, Y. (2014). The Effect of Eight-Week Workout Specific to Basketball on Some Physical and Physiological Parameters. Procedia - Social and Behavioral Sciences. 152, 1288-1292. https://doi.org/10.1016/j.sbspro.2014.09.364

Özbek, S. (2008). 15-17 Yaş Grubu Erkek Basketbolcularda Hazırlık Dönemi ve Üst Ekstremite Kuvvet 
Antrenmanlarının Bazı Parametrelere ve Şut İsabetine Etkisi (Yüksek Lisans Tezi). Niğde Üniversitesi, Niğde.

Özer, K. (2006). Fiziksel Uygunluk, 2. Bask1. Nobel Yay, Ankara.

Pamuk, Ö.. Kaplan, T., Taşkın, H., \& Erkmen, N. (2008). Basketbolcularda Bazı Fiziksel ve Fizyolojik Parametrelerin Farklı Liglere Göre İncelenmesi. Spormetre Beden Eğitimi ve Spor Bilimleri Dergisi, 6(3), 141-144. https://doi.org/10.1501/Sporm_0000000101

Rhea, M. R., Peterson, M. D., Oliverson, J. R., Ayllón, F. N., \& Potenziano, B. J. (2008). An examination of training on the VertiMax resisted jumping device for improvements in lower body power in highly trained college athletes. The Journal of Strength \& Conditioning Research, 22(3), 735-740. https://doi.org/10.1519/JSC.0b013e3181660d61

Savucu, Y., Polat, Y., Ramazanoğlu, F., Karahüseyinoğlu, M.F., Biçer, Y.A. (2004). Alt Yapıdaki Küçük, Yıldız ve Genç Basketbolcuların Bazı Fiziksel Uygunluk Parametrelerinin İncelenmesi. Firat Üniversitesi, Sağllk Bilimleri Tip Dergisi, 18(4), 205-209.

Tamer, K. (2000). Sporda Fiziksel-Fizyolojik Performansın Ölçülmesi ve Değerlendirilmesi. Geliştirilmiş 2. Baskı, Bağırgan Yayınevi Kültür Matbaası, Ankara.

Taşkın, C., Karakoç, Ö., Nacaroğlu, E., \& Budak, C. (2015). Futbolcu çocuklarda seçilmiş motorik özellikler arasındaki ilişkinin incelenmesi. Spor ve Performans Araştırmalart Dergisi, 6(2), 101-107. https://doi.org/10.17155/spd.74072

Zorba, E. (1999). Herkes İçin Spor ve Fiziksel Uygunluk. G.S.G.M. Eğitim Dairesi, Ankara.

Zorba, E., \& Saygın, Ö. (2009). Fiziksel Aktivite ve Fiziksel Uygunluk. (İkinci Bask1). İstanbul: İnceler Ofset Matbaacilık.

\section{Copyrights}

Copyright for this article is retained by the author(s), with first publication rights granted to the journal.

This is an open-access article distributed under the terms and conditions of the Creative Commons Attribution license which permits unrestricted use, distribution, and reproduction in any medium, provided the original work is properly cited. 